\section{Going organic}

Question: when is a house not a house? Answer: when it's designed organically. For then it is more than a house, says David Pearson in his book New Organic Architecture: The Breaking Wave (University of California Press, $\$ 60, \mathfrak{E 4 0}$

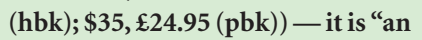
organism, an indivisible whole, and humans are seen as part of nature, not above her". The 'organism' shown here overlooks the ocean, and its flowing motifs are meant to reflect the sea's proximity. was a police matter and not a health issue. In the United States, Richmond Hobson, Bishop Brent and Harry Anslinger - who headed the Federal Bureau of Narcotics for more than 30 years - were among the prime movers. They refused to see drug abuse as a medical problem that afflicted particularly the socially deprived poor. This policy culminated in the era of Richard Nixon and Ronald Reagan with the 'war on drugs'.

Davenport-Hines gives a scathing account of the failures of the US drug policy. It generated a new capitalist industry of illicit supply and was responsible for virtually destroying the social fabric of Colombia and other Latin American countries. Among the greatest blunders was the policy adopted by the CIA in Afghanistan, where the rebels fighting the Soviet Union were encouraged to finance their war by sales of opium. By 1980, two-thirds of all supplies of heroin in the United States came from Afghanistan. The policy of banning marijuana as a dangerous narcotic also generated disbelief in a generation of young people who no longer took any government advice on drugs seriously.

Things were only slightly better in Europe, although the British and Dutch were initially sceptical about policies banning opium use in their Far Eastern colonies, where such use was centuries old. At home, freedom of manoeuvre was increasingly restricted by international agreements on drug prohibition through the League of Nations and later the United Nations. But Britain had always viewed the medical model of addiction sympathetically, and heroin addicts were registered and given maintenance treatment until the 1970s. The Dutch also broke away to experiment with the decriminalization of cannabis and its supply through registered 'coffee shops'. Thankfully, drugs policy is now

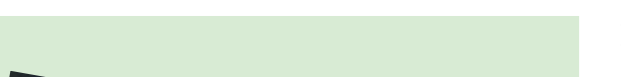

political implications of literacy, and concludes with some interesting speculation on the possible future of writing in an age of computer icons and voice recognition. All readers are likely to learn something new or to encounter a question they had never thought about before.

Indeed, a number of Fischer's facts and ideas are new in their own right. The most interesting of these is the attractive theory originated in 1966 by Pierre Amiet of the Louvre and most actively promoted by Denise Schmandt-Besserat at the University of Texas at Austin - that writing began with accountancy symbols: first, clay tokens, then clay tokens sealed in clay envelopes, then with a count of the contents scratched on the outside as a kind of 'bill of lading' to guarantee against fraud. The theory is new because the tokens, small lumps of clay, are not impressive artefacts in their own right and were overlooked by earlier archaeologists.

It is often assumed that what wins must be best. But this is questionable. Arabic numerals may have found favour in the West not because they made calculation easier but because they saved space. The alphabet is not inevitably more efficient than a syllabary; it depends on the language. And our present Latin alphabet, even though it now bids fair to conquer the world, is not the best possible one. It has only 26 letters, whereas most languages have around 40 significant speech-sounds or phonemes; its duplication of upper- and lower-case lettering is quite unnecessary, and the letter shapes themselves - however explicable from a historical point of view - are quite irrational.

Ugaritic, a writing system used on the Syrian coast in the fifteenth century BC, was more intelligent: it had 30 signs constructed on a minimalist scheme, and those that were quickest to draw were allocated (or so it would seem) to the most frequent sounds. And in the fifteenth century AD, Korea's Hankul script was a syllabary created on advanced linguistic principles, with its letters designed to show the position taken by the vocal organs in articulating the sounds - a unique feature. Yet even though it was promulgated by royal authority - by Sejong, fourth king of the Yi dynasty - it was despised by traditional scholars and its use only became general after the Second World War, when changes in spoken language had rendered it a less perfect instrument. Indeed, as Fischer shows, social prestige and political power have always outweighed intrinsic merit in deciding which scripts become dominant. As for reforming the highly inconsistent spelling habits of present-day English, not only have proposed reforms never succeeded in practice, but they may even be undesirable in theory. Fischer can quote authorities as diverse as Noam Chomski and A. P. Herbert in favour of leaving the apparent chaos alone.

The book has faults. There are signs of 
haste — lists ending lamely with an "etc." or "and so forth". Dating the Indian Kharosthi script to "the first few centuries BC" is careless writing when what he means is the last few. It is not always clear when Fischer is writing on his own authority and when he is following a secondary source. He can even send us to a general book on the alphabet written 60 years ago as his support for saying that the Arabic and Hebrew scripts are both historically tied to a particular religion. This is odd rather than sinful. But to tell us something that is not generally accepted - such as that Cyprus is the place of origin of the Greek alphabet - without providing evidence, is less excusable. It is worse still when Fischer states that the undeciphered pre-Mycenaean Cretan scripts (including the notorious Phaistos Disk) have been deciphered as Greek. The 'decipherment', however, is Fischer's own and hardly anyone else accepts it. The claim is one that should not have been made in a general book where it is likely to mislead non-experts.

But unwavering orthodoxy would be dull. What is wonderful is to see a subject that embraces so much of human civilization handled with the wide knowledge and breadth of vision that it deserves.

Maurice Pope is at 26 Lathbury Road, Oxford OX2 7AU, UK.

New in paperback by the same author A History of Language

by Steven Roger Fischer

Reaktion Books, £9.95, \$17.95

\section{Golem schmolem}

\section{Kiln People \\ by David Brin \\ Tor: 2002. 336 pp. $\$ 25.95$ \\ Henry Gee}

According to Jewish folklore, a sixteenth-century rabbi of Bohemia called Yehuda Loew devised an antidote to anti-Semitic attacks: a vengeful automaton made of clay, animated with a scrap of parchment bearing one of the ineffable names of God. This automaton was called the golem. The story of Rabbi Loew, however, is not unique. The golem is mentioned in the Talmud, that sprawling compendium of ancient Jewish scholarship — in which, among other matters, scholars debated whether a golem was human enough to make a congregation quorate.

The Talmud, then, was arguably the first forum to debate the legal and social status of artificial people. The Western canon caught up in 1818, with the publication of Mary Shelley's novel Frankenstein. Like the passages in the Talmud that talk of the golem, Frankenstein is an extended debate on whether the feelings and motivations of artificial people can be judged as equivalent to those of humans.

The modern concept of automata, like the legend of Rabbi Loew, was a thoroughly

\section{On the jungle beat}

A day gecko (Phelsuma madagascariensis), below, and a cercopithecus (Cercopythecus mona). From Secret Jungle by Nicole Viloteau

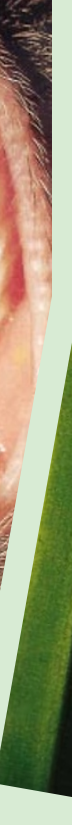

(Flammarion, \$40).

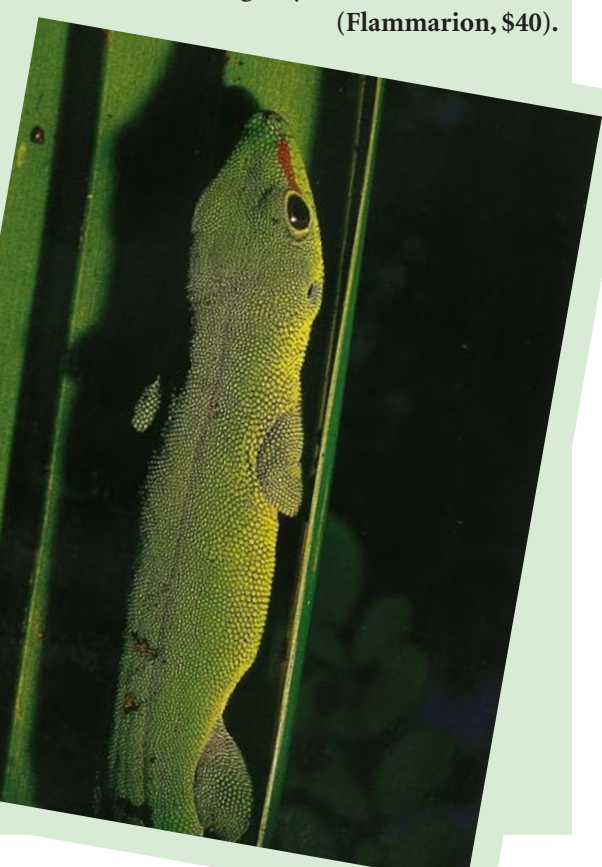

Bohemian rhapsody. In 1921, the Czech dramatist Karel Capek staged his play RUR ('Rossum's Universal Robots'). In Czech, the word robota means work, but with overtones of the obligations of serfdom. Capek was the first to use 'robot' to mean an automaton in the guise of a human being, created to do the jobs that real-life humans found dull. Since then, robots have been a staple of science fiction, from Isaac Asimov's robot stories of the 1950s to the droids of Star Wars fame and the replicants of Blade Runner, Ridley Scott's film based on Philip K. Dick's story Do Androids Dream of Electric Sheep?

David Brin's latest novel brings the golem up to date. Kiln People is a detective story set in a world in which making golems is as easy as making toast. Universal Kilns, a vast conglomerate, supplies citizens of the future with inert clay mannequins which, when animated with the imprint of the customer's 'soul wave' and baked in a kiln, produce replicas of the user that can be despatched on all sorts of errands, from doing the shopping to industrial espionage and even armed combat. After a light breakfast, you can imprint a few golems, send them off to work, and spend the rest of the day playing golf. At the end of the day, your golems (Brin calls them 'dittos') will return home, download their experiences into your brain, and dissolve into a recyclable, clayey sludge.

Kiln People centres around the exploits of gumshoe Albert Morris, who specializes in tracking down counterfeiters who churn out cheap knock-offs of 'pleasure' dittos imprinted with the soul waves of celebrity courtesans. Morris is a twenty-secondcentury Sam Spade, and at one level, Kiln People is a stylish noir thriller that follows all the conventions of the genre. Morris is the brilliant-yet-flawed loner amid a cast of stereotypes: there are wise-cracking villains, gun-toting mobsters, enigmatic and beautiful ladies with dark secrets and super-wealthy sugar-daddies.

So far, so LA Confidential. The twist is 'dittotech', which allows Morris - and everyone else - to be in several places at once, packing more incident into a day than most people could handle in a month. The plot is serpentine, to say the least, and the reader has to be able to follow several parallel plot strands as various copies of Morris - and Morris himself - investigate a seemingly endless brew of intrigue, double-cross and treble-bluff. At times the story threatens to collapse into chaos, like a golem at eventidebut it is saved by a use of language as artful as that of Chandler or Hammett. ("Me, I was one of a vanishing breed - the employed," says Morris. "Why stay in school when you have a marketable skill? You never know when it'll become obsolete.") Everything pulls together at the last minute in a suitably apocalyptic ending involving the archetypal mad scientist — but, hey! I'm telling you the plot. 